\title{
Nesting behavior of Bornean immature Orangutan (Pongo pygmaeus wurmbii) in Nyaru Menteng Arboretum School, Palangka Raya, Central Kalimantan, Indonesia
}

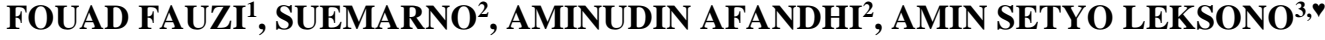 \\ ${ }^{1}$ Department of Forestry, Faculty of Agriculture, Universitas Palangkaraya. Jl. Yos Sudarso, Palangka Raya 74874, Central Kalimantan, Indonesia \\ ${ }^{2}$ Faculty of Agriculture, Universitas Brawijaya. Jl. Veteran, Malang 65145, East Java, Indonesia \\ ${ }^{3}$ Deparment of Biology, Faculty of Mathematics and Natural Sciences, Universitas Brawijaya. Jl. Veteran, Malang 65145, East Java, Indonesia. \\ Tel.: +62-341-575841, Fax.: +62-341-554403, `email: amin28@ub.ac.id
}

Manuscript received: 26 February 2020. Revision accepted: 23 April 2020.

\begin{abstract}
Fauzi F, Suemarno, Afandhi A, Leksono AS. 2020. Nesting behavior of Bornean immature Orangutan (Pongo pygmaeus wurmbii) in Nyaru Menteng Arboretum School, Palangka Raya, Central Kalimantan, Indonesia. Biodiversitas 21: 2172-2179. This research aimed at analyzing the nesting behavior of Bornean Orangutan (Pongo pygmaeus wurmbii) in Nyaru Menteng Arboretum, Palangka Raya, Central Kalimantan, Indonesia. The objects of observation were the immature orangutan nest, and the type of nest tree. The purposive sampling technique was used because not all immature Orangutan could make a nest. The Focal animal sampling method was used to determine the daily behavior and nets building activity. It involved observing and recording the behavior of five young Orangutans over a certain period of time and analyzing the nest made. The results of the study established that the daily activity of immature Orangutan on an average sequentially ranges from feeding $17.18 \%$, moving $23.92 \%$, resting $26.34 \%$, and social behavior $32.57 \%$. The process of making a nest begins with finding a suitable branch, bending and breaking twigs, and then arranging the twigs and leaves as a mattress. The duration of building a nest was 5.00 to 6.44 minutes, the preferred nest tree was Palaquium xanthochymum and Shorea spp., and the direction of the nest more facing west.
\end{abstract}

Keywords: Behavior, Dipterocarpaceae, imature Orangutan, Kalimantan, nesting, Pongo pigmaeus

\section{INTRODUCTION}

Orangutans are the only great apes that remain exist in South East Asia and live in restricted habitat in Borneo (Kalimantan) and Sumatra Islands. Base on morphometric, behavioral, and genomic evidence, Orangutans were classified into three species, i.e., Sumatran Orangutan (Pongo abelii), Tapanuli Orangutan (Pongo tapanuliensis) and Bornean Orangutan (Pongo pygmaeus) (Nater et al. 2017). Within Pongo pygmaeus population, there are three subspecies of Bornean Orangutan: Pongo pygmaeus morio, P.p. pygmaeus, and P.p. wurmbii (Bani et al. 2018). In 2004 there were c. 6,500 P. abelii remaining on Sumatra and at least 54,000 P. pygmaeus on Borneo (Wich et al. 2008).

The Orangutan densities vary between habitat types within regions and within similar habitat types among regions. Habitat loss and destruction, such as the conversion of forest to plantations, agriculture, mining, as well as forest fires are the main cause of their decline (Hockings et al. 2015; McKinney 2015). Hunting also contributes to the decrease in population. In many instances, people kill the parent to get her immature, rendering the young orphans. It seems that Orangutans are vulnerable to poaching but appear to be flexible in responding to several other human activities such as land cultivation (Spehar et al. 2018). When the forest destructed, they often encroach on cultivated land (Campbell-Smith et al. 2011). The Orangutans showed a strong foraging preference for mixed farmland/degraded forest habitat over oil palm patches. Most wild populations will disappear over the next few decades unless threats are abated. Saving Orangutans are ultimately in the hands of the governments and people of Indonesia, which need to ensure that habitats of viable Orangutan populations are protected from deforestation and forest degradation (Meijaard et al. 2010). Differently from previous studies Russon et al. (2015), reported that behavioral adjustment of Orangutans was flexible and influenced by multiple factors.

Efforts to preserve Orangutans need to be supported by appropriate strategies. Two main strategies are being undertaken to preserve Orangutans in general: (i) rehabilitation and reintroduction of orangutans who are captured or moved; and (ii) protection of their forest habitat to reduce threats such as deforestation and hunting (Wilson et al. 2014). For these purposes, some reintroduction centers have been set up to accommodate immature Orangutans, including ex-captive infants and juveniles. The center aspires to improve Orangutan living through rehabilitation them to adapt to living in their home ground.

The forestry school in the reintroduction center for immature Orangutans train them to acquire skills and social interaction, especially learning techniques and behaviors such as searching the forest safely. These skills learned include searching for food, identifying and avoiding predators, climbing trees (Jule et al. 2008), making nests 
and socializing with others (communication, friendship, settlement of conflicts between them) (Russon et al. 2007). Generally, Orangutan behavior research is mostly related to foraging or movement behavior (Manduell et al. 2011, Kanamori et al. 2010). Current results indicate that measured on a local scale, primate biomass and the number of species are affected by seasonal variations in food availability (Hanya et al. 2011; Vogel et al. 2017).

One of the lessons in the forestry school is to build a nest so that Orangutans are trained to rest in the right place. Sleep is a vulnerable state for animals because it compromises the ability to detect predators. The evolution of building a nest might be a solution to overcome this, which allows large-bodied apes to sleep lying in a safe and comfortable place (Stewart and Pruets 2013). Building nests are a daily activity of Orangutans. Nests support considerable social activity, such as resting, play, sex, and grooming together. The behavior goes from infancy (1-1.5 y. a.) by adding a lining to the mother's nest. For immature Orangutans, the nest is employed for playing, grooming, sheltering, feeding, and socialize with other Orangutans (Russon et al. 2007). Several studies reported nesting behavior; only a few are documented in rehabilitant Orangutans. Nevertheless, the factors and movements of trees selected for nesting are remaining unclear.

Building a nest for immature is one of the most important skills for rehabilitant Orangutans (Descovich et al. 2011). The rehabilitated infants grow into a juvenile and develop their life skills to increase their survival in the natural habitat. This is done to support the success of conservation objectives. The purpose of this study was to analyze the nesting process and tree preferences chosen by rehabilitant immature Orangutans.

\section{MATERIALS AND METHODS}

\section{Study area}

This research was conducted at the Nyaru Menteng Arboretum (NMA) school, Palangka Raya, Central Kalimantan, Indonesia. The school is part of the Orangutan Reintroduction Center Program managed by the Borneo Orangutan Survival Foundation. The area is situated at the NMA area $\left(113^{\circ} 46^{\prime}-113^{\circ} 48^{\prime} \mathrm{E}\right.$ and $\left.2^{\circ} 0^{\prime}-2^{\circ} 02^{\prime} \mathrm{S}\right)$ which is situated in the forest group of the Kahayan River and is situated East of the Tjilik Riwut Highway Km 28 from Palangka Raya to Katingan Regency, Central Kalimantan. The NMA, with an expanse of 65.2 ha, is a conservation area of the germplasm of the peat swamp forest ecosystem in Central Kalimantan Province. Since 1999, a large part of the NMA has been employed for the Orangutan Reintroduction Center, covering 1.5 ha in the clinical area, 4-6 hectares for the immature school, and 8 ha for the midway. Outside arboretum, there were some areas managed by an Orangutan Reintroduction Project, including Palas island with an area of 22 ha, 120 ha of Kaja island, and 35 ha of Bangamat island. These three islands are located close to NMA. The types of vegetation in this area represent of the characteristic of swamp forest ecosystems. The formation of vegetation in swamp forests has a long history, and they are able to adapt to waterlogged soils both seasonally and permanently throughout the year. This adaptation is shown by many supporting and buttress roots for air diffusion. The vegetation composes of ramin (Gonystylus bancanus), meranti rawa (Shorea spp.) mahang (Macaranga maingayi), gerumpang (Cratoxylon arborescens), makakang (Melastoma sp.), dragon lime (Dryobalanops sp.), kempas (Koompasia malaccensis), rengas (Gluta renghas), belawan (Tristaniopsis obovata), balangeran (Shorea balangeran), and punak (Tetramerista glabra).
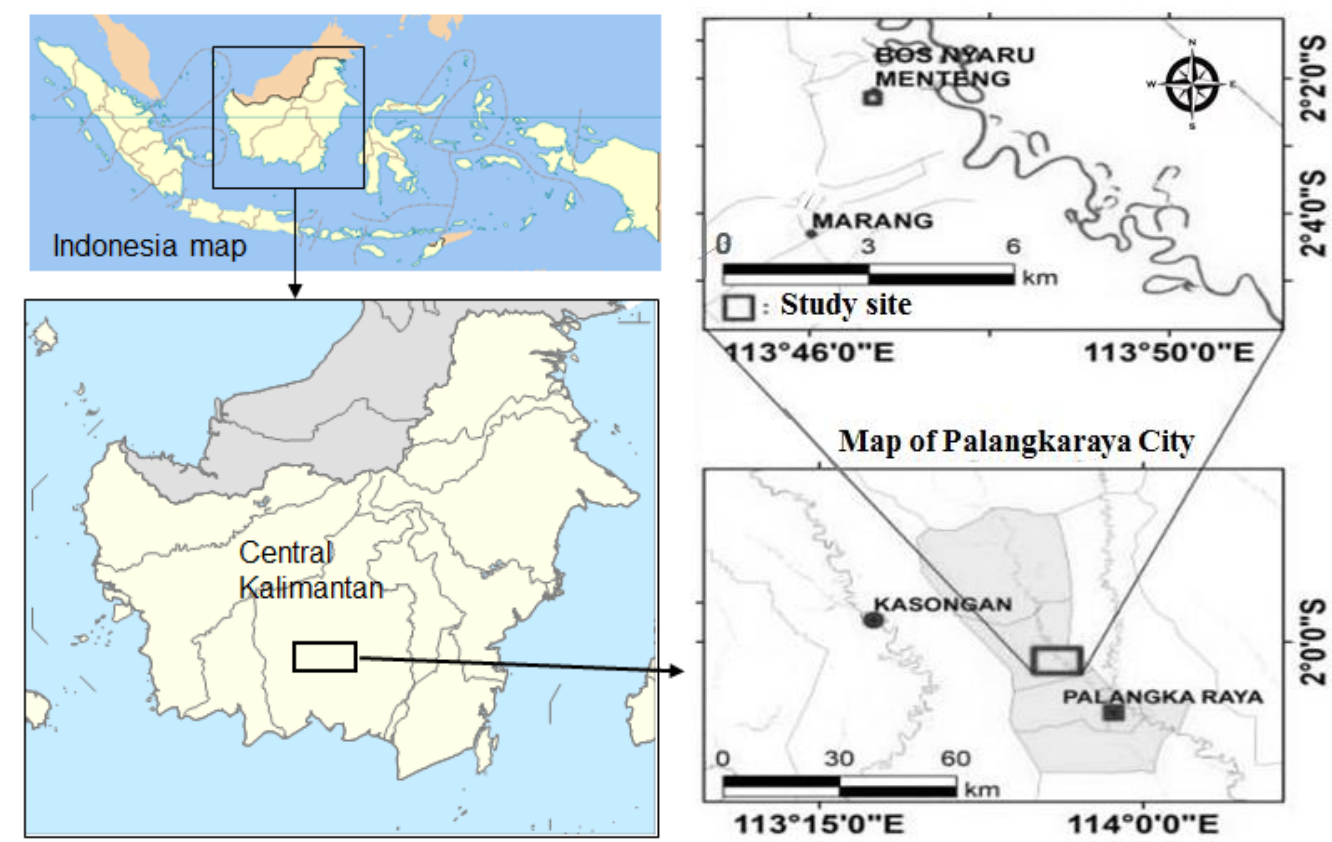

Figure 1. Location map of study sites in the central of Borneo, Indonesia (Fauzi et al. 2019) 
Other wildlife inhabiting the NMA includes the common hill myna (Gracula religious) and the strawheaded bulbul (Pyononotus zeylanicus). In addition, there are other species such as monitor lizards (Varanus sp.), snakes, squirrels, mouse deer and some primate species such as Orangutans (Pongo pygmaeus), gibbons (Hylobates muelleri) Maroon langur (Presbytis rubicunda), the longtailed macaque (Macaca fascicularis) and the southern pigtailed macaque (Macaca nemestrina). Furthermore, in this area, there are also types of plants Nepenthes, $N$. rafflesiana, $N$. maxima, $N$. ampullaria and $N$. gracilis, while the other types are Aglaonema sp., Dianella sp., Cryptosperma sp., and Nephrolepis sp. (Fauzi et al. 2019).

\section{Object and sampling method}

The objects of observation were the immature Orangutan, nest, and nest tree species in NMA school (Table 1). The focal animal sampling method was adopted to observe and record the behavior of the immature. The observation was done three to four hours daily for a period of 41 days. The nest building was observed when the immature start to build a nest. The NMA staff monitoring rehabilitates concurrently also contributed reports of nesting and corroborated observational assessments of nesting skills. Analysis of vegetation was done using a Point Centered Method with a radius of $10 \mathrm{~m}$ consist of 23 plots.

\section{Data analysis}

Data obtained from the results of recording, measurement, and calculation underwent descriptive analysis.

Table 1. The immature Orangutans observed in this study

\begin{tabular}{|c|c|c|c|c|}
\hline $\begin{array}{l}\text { Names of } \\
\text { immature }\end{array}$ & $\begin{array}{c}\text { Immature } \\
\text { code }\end{array}$ & $\begin{array}{c}\text { Age } \\
\text { (years) }\end{array}$ & Origin & $\begin{array}{c}\text { length of time } \\
\text { in captivity }\end{array}$ \\
\hline$\overline{\text { Kejora }}$ & $\mathrm{A}$ & 3 & Rescued & 1 month \\
\hline Malia & B & 5 & Rescued & 3 years \\
\hline Fatia & $\mathrm{C}$ & 3 & Rescued & 1 month \\
\hline Syahrini & D & 4 & Born at NMA & None \\
\hline Suci & $\mathrm{E}$ & 2 & Rescued & 7 days \\
\hline
\end{tabular}

Table 3. Taxonomy of nest trees in NMA Orangutan's Schools

\section{RESULTS AND DISCUSSION}

\section{Daily activity of immature Orangutans}

Our result showed that the daily activity of immature Orangutans in include feeding $17.18 \%$, moving $23.92 \%$, resting $26.34 \%$, and social behavior $32.57 \%$ (Table 2 ). The high level of social activity shows that infant and juvenile Orangutan need more playing activities, including wrestling with fellow friends, playing water and mud, wood or twigs, swinging in the roots, or playing in trees. Compared to other studies, this study showed a higher social behavior and resting. In the research carried out in the rehabilitation group it seen that the prominent activity was feeding followed by resting (Kuncoro 2004). While other studies stated the most research in juvenile and adult groups were resting followed by feeding (Fonna et al. 2015; Purnawan et al. 2016).

\section{Building nest}

This study identified nine plant species were frequently used as nest materials. A list of the species, along with its taxonomy, was presented in Table 3.

Besides using the tree, the immature also using liana for a mattress. The liana also served other functions as food and supporting tools for moving between trees for larger Orangutans. The following is a picture of the Orangutan nest taken during the research (Figures 2 and 3).

Table 2. Daily activities of immature Orangutan in NMA Schools

\begin{tabular}{ccccc}
\hline \multirow{2}{*}{$\begin{array}{c}\text { Immature } \\
\text { code }\end{array}$} & \multicolumn{4}{c}{ Daily activities (\%) } \\
\cline { 2 - 5 } & Feeding & Moving & Resting & Social behavior \\
\hline A & 10.42 & 27.09 & 36.46 & 26.04 \\
B & 20.83 & 19.80 & $26.05^{*}$ & 33.33 \\
C & 16.09 & 27.94 & 19.2 & 36.79 \\
D & 21.88 & 17.71 & $18.75^{* *}$ & 41.67 \\
E & 16.67 & 27.06 & 31.23 & 25.01 \\
& 17.18 & 23.92 & 26.34 & 32.57 \\
\hline
\end{tabular}

Note: * building nests twice daily; $* *$ building a nest and resting inside

\begin{tabular}{lllll}
\hline \multicolumn{1}{c}{ Species name } & \multicolumn{1}{c}{ Local name } & \multicolumn{1}{c}{ Family } & \multicolumn{1}{c}{ Order } & Division \\
\hline Koompassia malaccensis & Bengaris & Fabaceae & Fabales & Magnoliopsida \\
Shorea pallidifolia & Meranti Batu & Dipterocarpaceae & Malvales & Magnoliopsida \\
Dactylocladus stenostachys & Mertibu & Crypteroniaceae & Myrtales & Magnoliopsida \\
Stemonorus scorpioides & Pasir-pasir & Icacinaceae & Icacinales & Magnoliopsida \\
Syzygium zeylanicum & Gelam Tikus & Myrtaceae & Myrtales & Magnoliopsida \\
Parartocarpus venenosus & Lilin-lilin & Moraceae & Rosales & Magnoliopsida \\
Shorea smithiana & Lanan & Dipterocarpaceae & Malvales & Magnoliopsida \\
Palaquium xanthochymum & Mahalilis & Sapotaceae & Ericales & Magnoliopsida \\
Shorea spp. & Meranti & Dipterocarpaceae & Malvales & Magnoliopsida \\
\hline
\end{tabular}



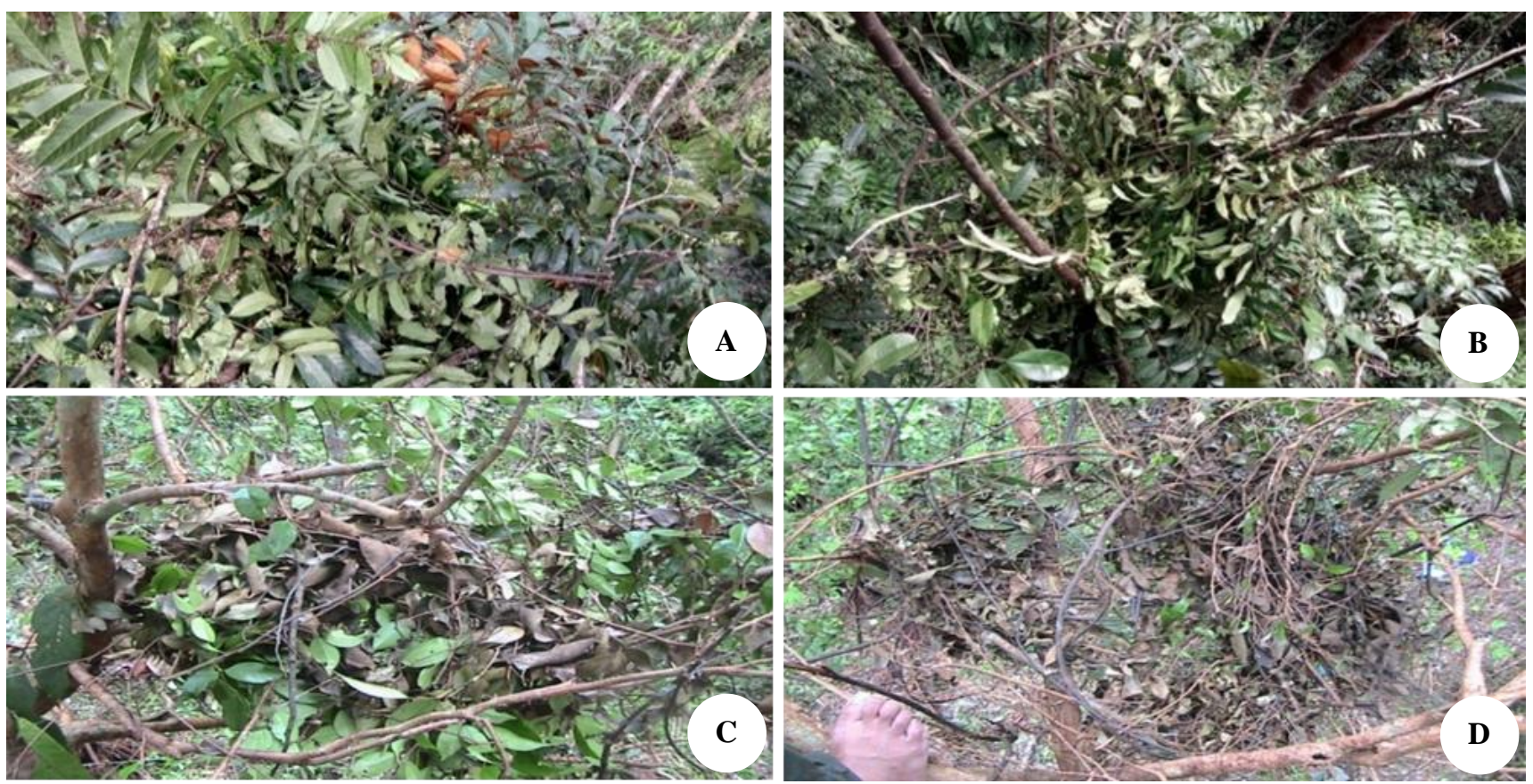

Figure 2. Nest construction of two immature A. and B. showing simple nests; C. and D. showing more detail nest with bending to build a bowl shape

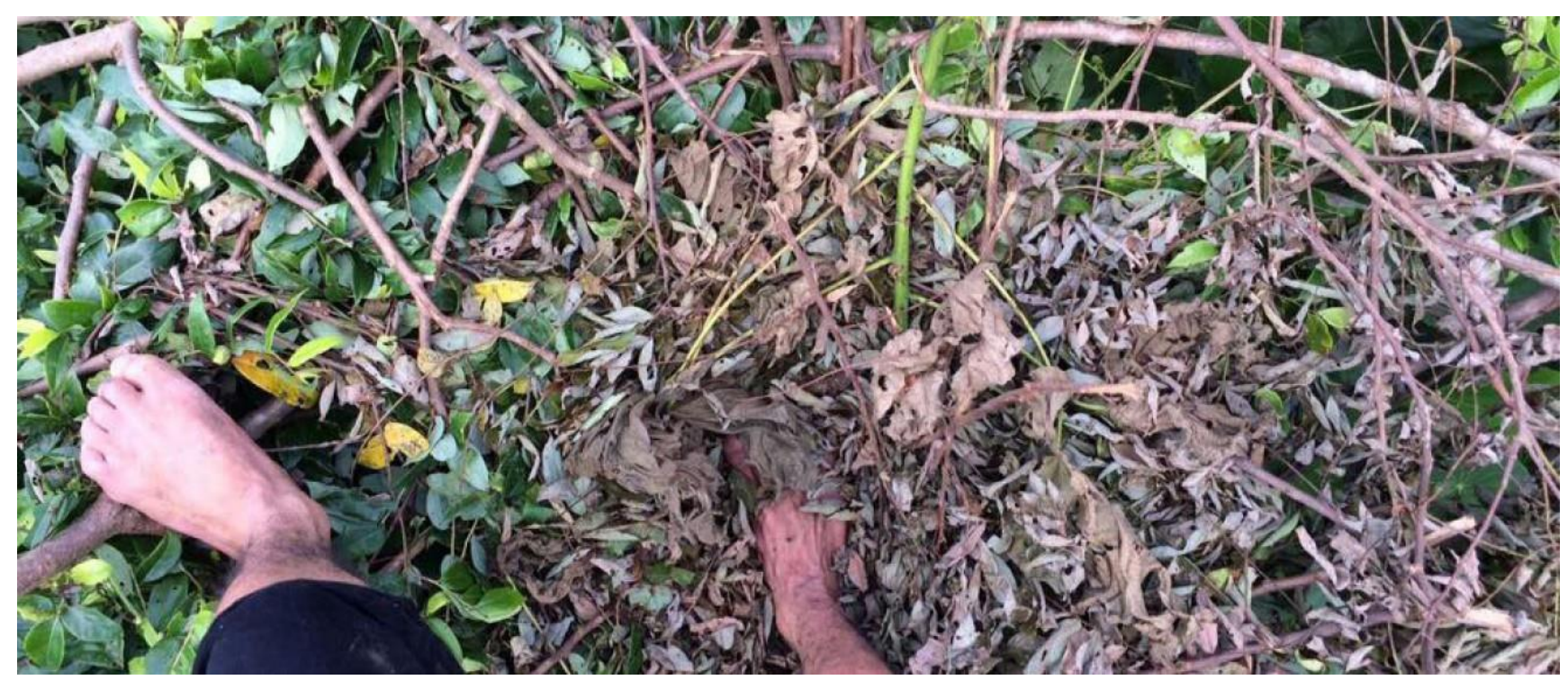

Figure 3. Mature Orangutan nest showing the complexity of structure and lots of tree species involved. This nest was located at the top layer of a tree or often also called a nest of type 3 (The Centre for Orangutan Protection 2017)

Table 4. Duration, position, and direction of a nest made by immature

\begin{tabular}{cccl}
\hline $\begin{array}{c}\text { Immature } \\
\text { code }\end{array}$ & $\begin{array}{c}\text { Duration } \\
\text { (minutes) }\end{array}$ & Direction & \multicolumn{1}{c}{ Tree species } \\
\hline $\mathrm{A}$ & 6.42 & North & Shorea spp. \\
$\mathrm{B}$ & 5.00 & West & Shorea spp. \\
$\mathrm{B}$ & 5.10 & North & Dactylocladus stenostachys \\
$\mathrm{B}$ & 5.03 & West & Palaquium xanthochymum \\
C and D* & 6.44 & West & Palaquium xanthochymum \\
\hline
\end{tabular}

Note: $\mathrm{C}$ and $\mathrm{D}$ build a tandem nest. Direction was observed based on the sun direction
Forest schools are very necessary for abandoned immature Orangutans because in this school they are taught how to make nests. In addition, immature groups will be taught how to climb trees by giving fruit to be given to immature Orangutans attached to the tip of a stick or pole and placed on the tree. The results of this study indicate the duration of building a nest is between 5.00 to 6.44 minutes, with most nests directed westward. Palaquium xanthochymum and Shorea spp. were the most frequently used trees to build a nest (Table 4). 


\section{Discussion}

This study showed that the prominent activity of five immature Orangutans was social behavior. Other behaviors were moving, feeding, or drinking milk, resting in the bush. While moving on wooden bridges the immature used to learn how to search food such as termites, ants, and other small animals. second rank activity was resting. Including in this activity was nesting behavior. Nesting activities by these immature Orangutans took $5.52 \%$ of their time. Descovich et al. (2011) study on juvenile Orangutans recorded $2.5 \%$ activity of nesting behavior (making, using, and repairing nests) from several daily activities, including feeding and social behavior (acting), moving.

The immature playing activities were higher compared to others, because they gathered in large numbers and as a result takes time playing with each other. Voice related activities were only carried out by three immature Orangutans, C, D, and B, while A and E were not observed. When playing near the babysitter, B was crying when looking at a small snake. This was considered a learning behavior obtained from the lessons given by the babysitter. so that the Orangutan learns could identify a predator, such as snakes, leopards, bears. The accomplishment of building a nest for an immature Orangutan came from the preparation offered by experienced babysitters. The learning activities starting from a baby school followed by an arboretum school, immature Orangutan, gained lessons on life skill and abilities that must be gradually assumed to get a mature Orangutan assessed and considered able to live on in the wild.

The role of other Orangutans in providing lessons to immature was observed from their social behavior. The nesting behavior occasionally was started from learning of the practice nests building. This kind of nest was just a result of their trial and soon abandoned thus never used as place for resting. When building nests, immature Orangutans learn a bunch from their peers and other nonkin (Russon et al. 2007). In their natural habitat, immature Orangutans develop a keen stake in visiting their mothers building nests. They start to exercise of building nests when they are about 0.5 years old (Prasetyo et al. 2009), and therefore parents take on a substantial function in teaching life skills to their young up to the degree of detachment immature Orangutans aged 3 years may build adequate nests, but remain sleep in their mother nests until they were weaned. The young Orangutan used to separate from its mother at aged 7-8 years. Contrastingly, the Sumatran Orangutan juvenile was cared for by its mother for 9 years, the longest animal in the world cared for by its mother.

From the research findings, there were 11 trees used by immature Orangutans for building nests, consisting of 9 species and 7 families. The number of trees, species and families was only in a small part of the forest school section because the area is around 65.2 ha in the NMA area. From the results of vegetation analysis carried out in the area around the NMA there were 25 species of trees from 16 families. Sleeping behavior is a typical behavior of several types of primates such as Hylobates pileatus, Pan troglodytes, Macaca leonina, Colobus vellerosus,
Nomascus nasutus. Primates generally choose sleeping sites in trees that are close to food sources and are large in size (Phoonjampa et al. 2010; Albert et al. 2011; Cheyne et al. 2012; Fei et al. 2012). For primates who are very closely related to humans, for example Macaca fascicularis proximity to the location of the nest is related to the location of the settlement (Brotcorne et al. 2014). Trees with diameter at breast height $(\mathrm{DBH})$ above the average and height, lacking lianas and wasp nests, and more often located within $5 \mathrm{~m}$ of open water tend to be preferred (Phoonjampa et al. 2010; Barnett et al. 2012; Cheyne et al. 2012; Fei et al, 2012). This study found that the immature nest was simple because they were remained in the learning stage. The following points of building the nest were observed: (i) An immature during the activity in choose a tree branch considered suitable for forming a nest without bearing in mind the type or the durability of the branch from the tree; (ii) An immature bend and snap off a branch and set it in such a manner that it form a nest bowl; (iii) Add accessories as a mattress by getting a few branches with lots of leaves so that it makes a comfortable layer to rest in.

In addition to the twigs of leaves made into mattresses, there are also other materials found in the nest such as lianas and Stemonorus scorpioides trees. From the nest arrangement, the twigs and lianas were mixed and made into a mattress, there was a liana so that the immature Orangutan easily reaches it. There are some evidences that carried leaves stretched from other trees and formed into nests used as mosquito repellents at night (MorroghBernard et al. 2017). Bringing leaves from another tree to build a nest is one of the cultures found in both wild and rehabilitant Orangutans, as experienced along the island of Kaja, Central Kalimantan (Russon et al. 2007). Often the snapping process failed due to bending failure (van Casteren et al. 2012a).

From the Figures 2 and 3, it can be seen that the immature nest in Figure 2 was simpler than mature nest (Figure 3). The nest shape and arrangement were also irregular, with the unsolid base. Even the base of the immature nest is very sturdy and can be climbed by humans. When compared to adult Orangutans preparing nests by immature was not followed by locking the nest with the intertwining branches until the nest is strong and can even be tested for strength by jumping up and down the nest. This is what distinguishes a practice nest from a real nest, an answer to why an Orangutan juvenile's nest was easily felt like a bird's nest and why they cannot last long (Prasetyo et al. 2009).

This study showed that the immature just able to build simple nests. This situation may be caused by a number of reasons, for instance, their learning behavior as wild animals have altered when they were caught by human. These instincts were lost because some Orangutans were former pets of the community and their daily lives were affected by human. For example, in the case of food, sometimes immature Orangutan was fed with rice.

There were some immatures who keep asking to be carried by the babysitter. This situation may delay their development, especially in acquiring its survival skills. The 
relationship between age and weight with the ability of an Orangutan to make a nest can be assumed to be directly related. This is also the case with weight, something reasonable because they need a strong nest and comfortable place to rest. The maturity is proportional to the increased ability and skill in building nests.

The Orangutans A, B, and C were known to actively build nests, with the former creating at least twice a day. It is the same as in wild immature Orangutans in Birawa, East Kalimantan, which makes 2 nests in 1 day (Rayadin and Saitoh 2009). The young Orangutans were able to build nests repeatedly, including night nest. However, they remain sleeps in the mother's nest. At the age of 7 , immature Orangutan begins to sleep in their own night nests. At this age the Orangutan juvenile will be weaned from its mother and classified as an adolescent, though, Orangutans aged 2.5-7 years are still categorized as immature.

The building nest skills were obtained from the parents directly starting from childhood. The relationship was interrupted when the parents killed as a result of hunting.

The role of the instructor, in this case the babysitter who nurtures and teaches skills greatly, determines the development of the Orangutan child, although later the results may be faster or slower compared to those taught directly by the parent. The existence of forest schools filled with immature Orangutan to socialize both from the community, immature born in different rehabilitation centers, gender and age also shape and accelerate the skills acquired, since they are not taught by their parents.

Our study observed that the immatures build nests in the morning with facing west direction. The morning nest was made when the young Orangutan started activities in the forest school, while night nests were constructed during the late evening used for beds and staying at night. In our observation, the existence of a night nest built by another immatures showed that the ability of this skill was considered sufficient and exceeds the minimum ability of the arboreal animal for releasing to its natural habitat. They build a night nest for bed every day to protect themselves from the threat of nocturnal predators. This situation was slightly different from the nests built by other Orangutans that were used only as a short break.

Generally, night nests were built better than ordinary one. For juvenile Orangutan in school, there were practice nests or training ones because they built weaker nest. This was reinforced by Prasetyo et al. (2009) which stated that Orangutans build nests during the day and night and what distinguishes them from nests is a simpler daytime nest and time to build a lower nest. The ability to make nests in Orangutans is one of the processes meant to attain independence and Orangutans who are already independent will make night nests as a place to sleep after a full day's activities (Russon et al. 2007).

From the table 5, it can be seen that the duration of time made by an immature Orangutan in building nests ranges from 5.00 minutes to 6.44 minutes, implying that immature Orangutan need time from compiling the nest foundation by breaking and arching tree branches to composing branches and leaves used for nest mattresses. The results of the study (Anonymous) by Syiah Kuala University on Sumatran Orangutan (Pongo abelii) at the Jantho Orangutan reintroduction station, Aceh Besar district noted that the duration of making a new nest ranged from 1 to 6 minutes. Other study also stated that the average time needed for Orangutans to make night nests was two to three minutes, while the fastest time is 9 minutes for adult Orangutans (MacKinnon 1974). According to van Casteren et al. (2012b), Orangutans will take 10 to 15 minutes to build their nests firmly.

In the line of the above, there is one interesting new thing, the existence of a "tandem nest" (this term was introduced since no such case had been found). Tandem nest meant 1 nest made by 2 immature Orangutans, not 1 nest used for sleeping by the mother and her junenile or 2 young Orangutans sleeping in a nest like the case in Birawa, East Kalimantan (Rayadin and Saitoh 2009).

The case of making tandem nests like this is hard to find in wild Orangutans. This is due to the nature of Orangutans living a semi-solitary lifestyle. Orangutan tend to emphasize their time to take care of their offspring or kin. Throughout her life, female Orangutans can only have four to five offspring.

When associated with nesting behavior between $\mathrm{C}$ and $\mathrm{D}$, it can be said that the $\mathrm{D}$ is included in the behavior of "imitation", conduct as a result of observation and imitating other animals, in this case C. This very positive thing because immature Orangutan can also learn from their friends by imitating what they do. That is why those studying in forest schools must be grouped with already skilled ones in implementing skills especially in building nests. The existence of this grouping will ease the burden that must be offered by the babysitter because of the limited ability to directly teach the Orangutan immature.

As a comparison, building nests according to Prasetyo et al. (2009) begins with the selection of tree species, making a base or frame of the nest by pulling several tree branches, establishing a foundation or mattress from a small branch usually with lots of leaves, locking nest by intertwining branches until the nest has a strong structure, adding special features or accessories such as pillows, blankets and the roof of the nest. It is clear that nestmaking was carried out by Orangutans who are already independent in making nests, wild adults or teenagers who every day make nests either day nests or night nests. A simpler Orangutan nesting activity, was the breaking or treatment of branches or plants to compose a nest that will be used for resting or sleeping, building a base for feeding, or protecting the body from rain. In this study, building nests started from choosing suitable branches. The branches were broken or bent, placed in an overlapping manner and finally covered with small branches. When viewed in terms of strength and durability, the nest was easily damaged or destroyed.

In conclusions, the process of making a nest by an immature Orangutan started with the selection of tree branches that were suitable for nesting, then bending or breaking branches to make a nest bowl and filling it with twigs with leaves to make a base. This process of making nest was simpler and different when compared to adult or 
young Orangutans. The duration of building a nest was 5.00 to 6.44 minutes, the preferred nest tree was Palaquium xanthochymum and Shorea spp., and the direction of the nest more facing west.

\section{ACKNOWLEDGEMENTS}

Our thanks go to the Ministry of Technology and Higher Education for the assistance, UB's Agricultural Science Doctoral Program, Yayasan BOSF Management Nyaru Menteng, who gave permission to use the research site. We also thank Muliyono, Sampang, Mrs. Sri Rahayu, and the Head of Natural Resources Conservation Agency and staff along with colleagues from the Central Kalimantan Orangutan Forum (Forkah) and the Indonesian Orangutan Forum (Forina).

\section{REFERENCES}

Albert A, Savini T, Huynen MC. 2011. Sleeping site selection and presleep behavior in wild pigtailed macaques. Am J Primatol 73 (12) 1222-1230.

Ashbury AM, Posa MRC, Dunkel LP, Spillmann B, Atmoko SSU, van Schaik CP, van Noordwijk MA. 2015. Why do orangutans leave the trees? Terrestrial behavior among wild Bornean orangutans (Pongo pygmaeus wurmbii) at Tuanan, Central Kalimantan. Am J Primatol 77 (11): 1216-1229.

Bani SN, Perwitasari-Farajallah D, Atmoko SSU, Sihite J. 2018. Adaptation behavior of Bornean Orangutan (Pongo pygmaeus morio) reintroduction in Kehje Sewen Forest, East Kalimantan, Indonesia. Biodiversitas 19 (3): 989-996.

Barnett AA, Shaw P, Spironello WR, MacLarnon A, Ross C. 2012. Sleeping site selection by golden-backed uacaris, Cacajao melanocephalus ouakary (Pitheciidae), in Amazonian flooded forests. Primates 53 (3): 273-285.

Brotcorne F, Maslarov C, Wandia IN, Fuentes A, Beudels-Jamar RC, Huynen MC. 2014. The role of anthropic, ecological, and social factors in sleeping site choice by long-tailed macaques (Macaca fascicularis). Am J Primatol 76 (12): 1140-1150.

Campbell-Smith G, Campbell-Smith M, Singleton I, Linkie M. 2011 Raiders of the lost bark: Orangutan foraging strategies in a degraded landscape. Plos One 6 (6): e20962. DOI: 10.1371/journal.pone.0020962

Cheyne SM, Höing A, Rinear J, Sheeran LK. 2012. Sleeping site selection by agile gibbons: The influence of tree stability, fruit availability and predation risk. Folia Primatol (Basel) 83 (3-6): 299-311.

Descovich KA, Galdikas BM, Tribe A, Lisle A, Phillips CJ. 2011. Fostering appropriate behavior in rehabilitant orangutans (Pongo pygmaeus). Int Primatol 32: 616-633.

Fei HL, Scott MB, Zhang W, Ma CY, Xiang ZF, Fan PF. 2012. Sleeping tree selection of Cao Vit gibbon (Nomascus nasutus) living in degraded karst forest in Bangliang, Jingxi, China. Am J Primatol 74 (11): 998-1005.

Fonna I, Sutekad D, Iqbar. 2015. Aktivitas harian Orangutan Sumatera (Pongo abelii) reintrodukasi di Stasiun Reintroduksi Orangutan Jantho, Kabupaten Aceh Besar. Prosiding Seminar Nasional Biotik. Aceh, 30 April 2015. [Indonesian]

Fauzi F, Soemarno, Afandhi A, Leksono AS. 2019. The nest decay rates of infant Bornean orangutans (Pongo pygmaeus wurmbii, Tiedemann 1808) at Nyaru Menteng Reintroduciton center in Palangkaraya Indonsia. Eco Env Cons 25: 20-28.

Hanya G, Stevenson P, van Noordwijk M, Te Wong S, Kanamori T, Kuze N, Aiba S, Chapman CA, van Schaik C. 2011. Seasonality in fruit availability affects frugivorous primate biomass and species richness. Ecography 34: 1009-1017.

Hockings KJ, McLennan MR, Carvalho S, Ancrenaz M, Bobe R. 2015. Apes in the Anthropocene: Flexibility and survival. Trends in Ecol and Evol 30: 215-222.
Jule KR, Leaver LA, Lea EG. 2008. The effects of captive experience on reintroduction survival in carnivores: A review and analysis. Biol Conserv 141: 355-363.

Kanamori T, Kuze N, Bernard H, Malim TP, Kohshima S. 2010. Feeding ecology of Borneo orangutans (Pongo pygmaeus morio) in Danum Valley, Sabah, Malaysia: A 3-year record including two mast fruitings. Am J Primatol 72: 820-840.

Kuncoro P. 2004. Aktivitas Harian Orangutan Kalimantan (Pongo pygmaeus Linnaeus, 1760) Rehabilitan di Hutan Lindung Pegunungan Meratus Kaltim. [Thesis]. Universitas Udayana, Bali. [Indonesian]

Manduell KL, Morrogh-Bernard HC, Thorpe SK. 2011. Locomotor behavior of wild orangutans (Pongo pygmaeus wurmbii) in disturbed peat swamp forest, Sabangau, Central Kalimantan, Indonesia. Am J Phys Anthropol 145 (3): 348-359.

McKinney T. 2015. A classification system for describing anthropogenic influence on nonhuman primate populations. Am J Primatol 77: 715726.

MacKinnon J. 1974. The behavior and ecology of wild Orangutans (Pongo pygmaeus). Anim Behav 22: 3-74.

Meijaard E, Albar G, Nardiyono, Rayadin Y, Ancrenaz M. 2010. Unexpected ecological resilience in Bornean orangutans and implications for pulp and paper plantation management. Plos One 5: e12813. DOI: 10.1371/journal.pone.0012813

Morrogh-Bernard HC, Foitová I, Yeen Z, Wilkin P, de Martin R, Rárová L, Doležal K, Nurcahyo W, Olšanský M. 2017. Self-medication by orang-utans (Pongo pygmaeus) using bioactive properties of Dracaena cantleyi. Sci Rep 7: 16653. DOI: 10.1038/s41598-01716621-w

Nater A, Maja P, Mattle-Greminger, Nurcahyo A, Nowak MG, Manuel M, Desai T, Groves C, Pybus M, Sonay TB. 2017. Morphometric, behavioral, and genomic evidence for a New Orangutan species. Curr Biol 27 (22): 3487-3498.

Phoonjampa R, Koenig A, Borries C, Gale GA, Savini T. 2010. Selection of sleeping trees in pileated gibbons (Hylobates pileatus). Am J Primatol 72 (7): 617-625.

Prasetyo D, Ancrenaz M, Morrogh-Bernard H, Atmoko SSU, Wich SA. 2009. Nest building in Orangutans. In: Wich SA, Atmoko SSU, Mitra ST, van Schaik CP (eds). Orangutans: Geographic Variation in Behavioral Ecology and Conservation. Oxford University Press, UK.

Purnawan H, Prayogo H, Anwari MS. 2016. Perilaku harian orangutan (Pongo pygmaeus) di Yiari Ketapang, Kalimantan Barat. Jurnal Hutan Lestari 4 (4): 628-637. [Indonesian]

Rayadin Y, Saitoh T. 2009. Individual variation in nest size and nest site features of the Bornean Orangutans (Pongo pygmaeus). Am J Primatol 71: 393-399.

Russon A, Handayani DP, Kuncoro P, Ferisa A. 2007. Orangutans leafcarrying for nest-building: Toward unraveling cultural processes. Ani Cogn 10: 189-202.

Russon AE, Kuncoro P, Ferisa A. 2015. Orangutan behavior in Kutai National Park after drought and fire damage: Adjustments to shortand long-term natural forest regeneration. Am J Primatol 77 (12): 1276-1289.

Spehar SN, Sheil D, Harrison T, Louys J, Ancrenaz M, Marshall AJ, Wich SA, Bruford MW, Meijaard E. 2018. Orangutans venture out of the rainforest and into the Anthropocene. Sci Adv 4 (6): e1701422. DOI: 10.1126/sciadv. 1701422

Stewart FA, Pruetz JD. 2013. Do chimpanzee nests serve an antipredatory function? Am J Primatol 75 (6): 593-604.

van Casteren A, Sellers WI, Thorpe SKS, Coward S, Crompton RH, Ennos AR. 2012a. Why don't branches snap? The mechanics of bending failure in three temperate angiosperm trees. Trees 26: 789797. doi.org/10.1007/s00468-011-0650-y

van Casteren A, Sellers WI, Thorpe SKS, Crompton RH, Julia M, Ennos, AR. 2012b. Nest-building orangutans demonstrate engineering knowhow to produce safe, comfortable beds. Proc Natl Aacad Sci USA 109 (18): 6873-6877.

Vogel ER, Alavi SE, Atmoko SSU, van Noordwijk MA, Bransford TD, Erb WM, Zulfa A, Sulistyo F, Farida WR, Rothman JM. 2017. Nutritional ecology of wild Bornean orangutans (Pongo pygmaeus wurmbii) in a peat swamp habitat: Effects of age, sex, and season. Am J Primatol 79: e22618.

Wich S, Meijaard E, Marshall A, Husson S, Ancrenaz M, Lacy R, Singleton I. 2008. Distribution and conservation status of the orangutan (Pongo spp.) on Borneo and Sumatra: How many remain? Oryx 42 (3): 329-339. 
Wilson HB, Meijaard E, Venter O, Ancrenaz M, Possingham HP. 2014 Conservation strategies for Orangutans: Reintroduction versus habitat preservation and the benefits of sustainably logged forest. Plos One 9 (7): e102174. DOI: 10.1371/journal.pone.0102174 